\title{
Polichromia w sieni Dworu Artusa w Toruniu jako jeden z elementów pruskiej polityki kulturalnej
}

Krystyna Dąbrowska

Gdańsk

Podczas zwiedzania toruńskiej starówki trudno przejść obojętnie obok wyróżniającego się zarówno swym imponującym rozmiarem, jak i odmienną stylistyką budynku XIX-wiecznego Dworu Artusa. Obecnie jest on siedzibą instytucji kulturalnej, miejscem rozmaitych uroczystości, festiwali i koncertów. Warto zwrócić uwagę na fakt, iż w budynku tym od zawsze odbywały się tego rodzaju wydarzenia. Można powiedzieć, że wraz z upływem stuleci, dzięki poszanowaniu tradycji, nic się pod tym względem nie zmieniło.

Podziw i zainteresowanie zwiedzających budzi nie tylko fasada, ale również wystrój wnętrz i zdobiące je dekoracje malarskie. Tematyka toruńskiego Dworu interesowała już wielu badaczy, a sam budynek doczekał się mniej lub bardziej szczegółowych opracowań. Warto jednak zauważyć, iż $\mathrm{w}$ żadnym $\mathrm{z}$ nich nie poświęcono uwagi dekoracji malarskiej znajdującej się na parterze budynku' ${ }^{1}$ Ta ciekawa pod względem ikonograficznym polichromia powstała na początku XX w., a więc w czasach, kiedy miasto pozostawało pod pruskim panowaniem - dobrze byłoby również odpowiedzieć na pytanie, czy i w jaki sposób malowidła wpisują się w pruską politykę kulturalną.

\footnotetext{
${ }^{1}$ Być może jest to spowodowane faktem, iż nie znajduje się ona w szczególnie reprezentacyjnym ani głównym miejscu budynku, a do jej wykonania nie użyto kosztownych materiałów, które zapewniłyby budzący podziw efekt (np. mozaika).
} 


\section{Dwór Artusa w średniowieczu}

Pierwsze dwory Artusa zaczęły powstawać w XIV w. w Prusach Zachodnich. Ustalono, że znajdowały się w takich miastach jak: Gdańsk, Toruń, Elbląg, Chełmno, Malbork, Ryga, Rewel, Stralsund oraz w trzech miastach Królewca (Stare Miasto Królewiec, Knipawa i Lipnik) ${ }^{2}$. Materiał źródłowy w odniesieniu do pierwotnych form z czasów średniowiecznych jest ubogi, podobnie jak substancja zabytkowa z tego okresu. Ocalały jedynie partie fundamentów i poziom murów piwnic budynków w Gdańsku, Toruniu, Chełmnie i Elblągu ${ }^{3}$. Najwcześniejsze wzmianki o dworach często są zbieżne $\mathrm{z}$ informacjami o gildiach kupieckich, widziano $\mathrm{w}$ nich bowiem ten sam typ organizacji. Właśnie w tym czasie - w XIII i na początku XIV w. - w Toruniu zaczęły powstawać pierwsze zgromadzenia o charakterze zawodowym i religijnym, a kupcy prawdopodobnie utworzyli własną gildię ${ }^{4}$. W literaturze przyjęło się więc, że pierwsze dwory związane były z najstarszymi domami kompanii kupieckich. Między innymi z tej funkcji wynikało usytuowanie pierwszych budynków. Ustalono, że stawiano je przy najistotniejszych traktach handlowych, najważniejszych ciągach komunikacyjnych, które często prowadziły do nabrzeża portowego. Można powiedzieć, że te specyficzne budynki municypalne stanowią źródło poznania ówczesnej sytuacji społecznej oraz kulturalnej. Są one niejako architektonicznym dokumentem. Zarówno bryła budynku, jak i jego wystrój oraz wyposażenie tworzą dzieło sztuki, mówiące wiele o ambicjach mieszczaństwa, które w pewnym momencie traktowało reprezentacyjność Dworu jako sposób na manifestację swojego statusu.

Już sama nazwa nadaje instytucji pewną powagę i nobliwość wskazuje ona oczywiście na związki z legendarnym królem Arturem ${ }^{5}$.

\footnotetext{
${ }^{2}$ E. Pilecka, Średniowieczne Dwory Artusa w Prusach Zachodnich. Świadectwo kształtowania się nowej świadomości mieszczańskiej, Toruń 2005, s. 5.

${ }^{3}$ Ibid., s. 30-31.

${ }^{4}$ A. Czacharowski, Toruń średniowieczny (do roku 1454), [w:] Toruń dawny i dzisiejszy. Zarys dziejów, pod red. M. Biskupa, Warszawa 1983, s. 52.

${ }^{5}$ Był to legendarny władca Brytów, prawy mąż, obrońca wszelkich cnót i wiary chrześcijańskiej. Jego postać była ideałem męstwa i rycerskości - króla Artura zalicza-
} 
Rycerze króla, aby uniknąć utrwalenia jakiejkolwiek hierarchii wewnątrz swej grupy, zasiadali przy Okrągłym Stole. Mit ten stał się wzorem kultury rycersko-dworskiej i kojarzony jest z zakładaniem dworów w większych miastach średniowiecznej Europy - miejsc spotkań bogatych patrycjuszy. Budynki te miały się wyróżniać poszanowaniem dla wspólnotowych koncepcji równości i braterstwa uczestników spotkań niczym rycerzy Okrągłego Stołu. Ich wnętrza miały charakter reprezentacyjny, ale nie hieratyczny. Gromadziły konkretną grupę, jednorodną społeczność. W tym miejscu należy zaznaczyć, że nazwa „Dwór Artusa” została poddana w literaturze pewnego rodzaju nadinterpretacji, co pociągnęło za sobą kojarzenie tych budowli jako od zawsze związanych $\mathrm{z}$ romantycznymi ideami dworsko-rycerskimi. Funkcje najwcześniejszych dworów świadczą o tym, że początkowo ich cele były stricte praktyczne, a nazwa spopularyzowana została dopiero w czasach nowożytnych ${ }^{6}$.

Ich fenomen polega na reprezentacyjności fasad i wnętrz, które pozostawały jednocześnie dostępne i „przyjazne”. Te okazałe, reprezentacyjne budowle łączyły funkcje oficjalne i rozrywkowe. Stanowiły one miejsce uroczystych obrad, omawiania interesów, wymiany informacji, a także wspólnego świętowania, biesiadowania i zabaw. Można powiedzieć, że były to ośrodki życia towarzyskiego patrycjatu. Do dziś ich najbardziej reprezentacyjne wnętrza stanowią godną oprawę dla najważniejszych spotkań z ludźmi kultury, zebrań władz miejskich, jak też koncertów i spektakli. Jest to dowód, iż tego typu miejsce od zawsze było i pozostaje niezbędne w przestrzeni miejskiej.

Oprócz kompanii kupieckich kolejnym rodzajem zgromadzeń, jakie łączono z najwcześniejszymi dziejami dworów Artusa, były stowarzyszenia religijne, a zwłaszcza bractwa św. Jerzego ${ }^{7}$. Ich tradycja miała

no do jednej z triad średniowiecznego toposu o Dziewięciu Bohaterach. Znalazł się on tam w sąsiedztwie tak zacnych postaci, jak Karol Wielki czy Gotfryd de Bouillon.

${ }^{6}$ Wraz z upływem czasu rola dworów zmieniała się. Ich model jako budynków municypalnych, w pewnym momencie przypominających ratusze, ukształtował się dopiero około XV w.

${ }^{7}$ Było to zgromadzenie o charakterze religijno-charytatywnym. Święty Jerzy był patronem rycerstwa, chrześcijańskim odpowiednikiem króla Artura (który, mimo iż był szlachetnym rycerzem, nadal pozostawał przedstawicielem tradycji pogańskiej). Sto- 
silny związek z kulturą rycerską - członkowie bractw urządzali ćwiczenia, pokazy, turnieje rycerskie, a także brali udział w nabożeństwach, biesiadach czy paradach. Łatwo się domyśleć, że finałem turniejów były uczty i bale organizowane w Dworze Artusa. Bractwo św. Jerzego spełniało ważną funkcję społeczną: turnieje służyły wykazaniu męstwa, przynosiły najszlachetniejszą sławę zdobytą podczas walki oraz pozwalały na wybicie się z niższych warstw społecznych ${ }^{8}$.

Pierwotne dwory z początków XIV w. w miarę potrzeb zastępowano coraz okazalszymi budynkami. Stopniowo priorytetem przy wyborze miejsca stawały się kwestie reprezentacyjności. Nowy Dwór w Toruniu pojawił się około $1385 \mathrm{r}$. w południowej pierzei rynku. Takie usytuowanie świadczy o tym, że znajdował się on w centrum miejskiego życia. Budynek ten najwyraźniej zaspokajał nowe potrzeby - w XV stuleciu nie miały miejsca poważne przebudowy. W połowie XVIII w. historia budynku Dworu Artusa z czasów średniowiecza powoli dobiegała końca. 29 lipca 1733 r., podczas silnej burzy, uszkodzone zostały okna i dach Dworu. Remont dachu wykonał murarz Antoni Rohn - budynek został pokryty czterystoma dachówkami polskimi. Naprawą okien zajęli się stolarz Michael Baltzer oraz szklarz Johann Winkler?. W latach 1724-1756 budowla pełniła funkcję siedziby zboru ewangelickiego. Z kolei podczas wojny siedmioletniej, w latach 1758-1762, kiedy miasto zajęte było przez wojska rosyjskie, Dwór Artusa był siedzibą cerkwi prawosławnej. Stan techniczny budynku pogarszał się coraz bardziej. Bez wątpienia częste zmiany jego przeznaczenia i tłumy, jakie przewinęły się przez wnętrze Dworu, nie wpływały korzystnie na jego kondycję. Ostatnie prace restauratorskie średniowiecznego budynku przeprowadzono w 1779 r. 14 czerwca 1802 r. przystąpiono

\footnotetext{
warzyszenia te istniały w większych miastach hanzeatyckich, zwłaszcza w tych związanych z państwem krzyżackim, takich jak Gdańsk czy Elbląg. Bractwo skupiało najbardziej znakomitych przedstawicieli rodów patrycjuszowskich i bogatych kupców, którzy trudnili się hanzeatyckim handlem. Było to stowarzyszenie ekskluzywne.

${ }^{8}$ Święty Jerzy nie był jedynym świętym patronem, z którym wiązano dwory. Przykładowo w Rewlu działała gildia imienia św. Olafa i św. Kanuta, a w Rydze występował kult św. Maurycego. Świadczy to o stopniowym zastępowaniu tradycji pogańskich chrześcijańskimi.

${ }^{9}$ Ibid., s. 21.
} 
do rozbiórki budynku, a na jego miejscu postawiono Teatr Miejski, oddany do użytku w maju 1829 r. ${ }^{10}$

\section{Toruński Dwór Artusa w XIX wieku}

Budowę nowego Dworu Artusa podjęto w drugiej połowie XIX w. Autorem projektu był radca budowlany Rudolph Schmidt ${ }^{11}$, współautorem zaś architekt Duszyński - jego nazwisko i podpis pojawiają się niekiedy na projektach tuż obok podpisu Schmidta. W lutym 1889 r. majster ciesielski Ulmer rozpoczął rozbiórkę starego budynku, za co otrzymał wynagrodzenie w wysokości trzystu marek ${ }^{12}$. Według projektu, nowa inwestycja miała stanąc na fundamentach dwóch sąsiednich kamienic. W „Gazecie Toruńskiej” z 27 czerwca 1889 r. pojawiło się następujące ogłoszenie:

Magistrat tutejszy ogłasza submisyę na dostawę 300 beczek cementu portlandzkiego do nowego wybudowania „Artushofu” i na przewiezienie 1500 tysięcy cegieł z miejskiej cegielni do miejsca, gdzie „Artushof” się buduje. $\mathrm{O}$ warunkach dowiedzieć się można w urzędzie miejskiej budowli. Oferty zapieczętowane, każdą $\mathrm{z}$ osobna, $\mathrm{z}$ właściwym napisem, przesłać należy do 5 lipca rb. godz. 11 i trzy czwarte przed południem do wspomnianego urzędu ${ }^{13}$.

Nowy Dwór oprócz funkcji kulturalnej miał pełnić również funkcje usługowo-gastronomiczne. W tym celu w 1890 r. rozpoczęto planowanie pomieszczeń. Projekt parteru zakładał restaurację i sklep. Na pierwszym piętrze planowano umieścić główną salę oraz pokój boczny przeznaczony na koncerty, zebrania i tego typu mniejsze wydarzenia. $\mathrm{Na}$

\footnotetext{
${ }^{10}$ Budowa trwała długo - miejsce na Rynku Staromiejskim czekało na następcę Dworu przez ponad dwadzieścia lat. Autorem projektu był miejski budowniczy Heckert.

${ }^{11}$ Budowniczy zapisał się $\mathrm{w}$ historii miasta także dzięki projektowi pierwszej w Toruniu stacji pomp na Starych Bielanach. Oprócz dużych, poważnych założeń Schmidt trudnił się wieloma drobnymi pracami. Były to na przykład projekty budynków dla miejskiej cegielni na Bydgoskim Przedmieściu czy propozycja ogrodzenia szkoły. Swą funkcję pełnił w mieście prawdopodobnie do 1895 r., następnie przeniósł się wraz z rodziną do Kilonii - J. Kucharzewska, Architektura i urbanistyka Torunia w latach 1871-1920, Warszawa 2004, s. 379.

${ }^{12}$ R. Heuer, Die Drei Artushöfe und der Junkerhof in Thorn, Thorn 1917, s. 69.

${ }^{13}$ Gazeta Toruńska z 27 VI 1889 r., nr 145, s. 3.
} 
drugim piętrze miały znajdować się garderoba i mieszkania dla służby. $\mathrm{Na}$ poddaszu planowano skład i sypialnie dla przyjezdnych ${ }^{14}$. Nowy budynek, gotowy w surowym stanie jesienią 1891 r., został oficjalnie oddany do użytku 12 grudnia tego roku ${ }^{15}$.

XIX-wieczny budynek zajął miejsce trzech działek średniowiecznych ${ }^{16}$. W projekcie nie zabrakło pomieszczeń typowo reprezentacyjnych - na parterze zaaranżowano dwie sale, na wyższe piętra prowadziła okazała klatka schodowa (schody trójbiegowe z podestami). Pierwsze piętro $\mathrm{w}$ przednim trakcie podzielono na dwie duże sale, wsparte na kamiennych kolumnach, przedzielone korytarzykiem z małą salką. Drugie piętro zaadaptowano na Salę Balową Wielką, wysokości dwóch kondygnacji. W tylnym trakcie umieszczono klatkę schodową oraz Salę Lustrzaną, doświetlaną jedynie przez witrażowy świetlik w plafonie. $\mathrm{W}$ trakcie tym znajduje się również druga klatka schodowa. Całą powierzchnię lewej oficyny bocznej przeznaczono na Salę Srebrną, a w oficynie tylnej - Salę Małą oraz Salę Malinową. Oprócz sal typowo reprezentacyjnych w Dworze znajdowały się również pomieszczenia prywatne, komunikacyjne i pomocnicze - typowo użytkowe. Wnętrza reprezentacyjne, których celem było zrobienie jak najlepszego wrażenia na gościach odwiedzających Torun, zdobiły bogate sztukaterie ${ }^{17}$.

Mówiąc o reprezentacyjności Dworu nie można zapomnieć o okazałej fasadzie budynku - architekt wyposażył ją w liczne elementy deko-

\footnotetext{
${ }^{14}$ Archiwum Państwowe w Toruniu, Akta miasta Torunia (dalej: APT, AmT), sygn. G, 3994, k. 55.

${ }^{15}$ Pierwotne założenia co do kosztów budowy, mówiące o 325 tysiącach marek, zostały prawie dwukrotnie przekroczone - całkowity koszt wyniósł ostatecznie 640 tysięcy marek, zob. R. Heuer, op. cit., s. 70.

${ }^{16}$ S. Szczerbiński, Dwór Artusa. Torun, Rynek Staromiejski 6: dokumentacja historyczno-konserwatorska, Toruń 1989, mps w Archiwum Wojewódzkiego Konserwatora Zabytków, s. 19.

${ }^{17}$ Najokazalsze znalazły się w Sali Wielkiej, na kasetonowym suficie, ścianach i balkonach, oraz w Sali Srebrnej na plafonie i fasetach. Drugim elementem, podkreślającym w szczególny sposób reprezentacyjny charakter wnętrz, były dekoracyjna stolarka okienna i drzwiowa oraz wielobarwne boazerie maskujące grzejniki ogrzewania centralnego, wzbogacone o złocone profile. Salę Lustrzaną zdobiły plafony pokryte intarsjowanymi płycinami oraz skrzydła drzwi z przedstawieniami roślinnymi i zoomorficznymi. Pomiędzy taflami luster umieszczono płyciny o dużej powierzchni, z malowanymi przedstawieniami o tematyce mitologicznej.
} 
racyjne, takie jak potężny boniowany cokół czy trójkątny naczółek wieńczący centralny portal. Dodatkowo okna, typu porte-fenêtre, mają wewnętrzne kamienne podziały: są trójdzielne, czteropoziomowe, zamknięte półkoliście, z klińcem na osi. Powyżej, pomiędzy każdym oknem, znajdują się cztery kute, rozmieszczone symetrycznie, ozdobne elementy tworzące jednakowe kompozycje ornamentalne. Każdą z kondygnacji oddzielono gzymsami. Całość wieńczy wydatny gzyms dwupoziomowy - w niższym poziomie umieszczono szereg arkadek, $w$ wyższym rząd tarcz herbowych z pustymi polami. W centralnej części gzymsu koronującego, na osi portalu, znajduje się herb Torunia w architektonicznej oprawie schodkowego szczytu. Dodatkowym elementem dekoracyjnym są czworoboczne wieżyczki flankujące gzyms. Podstawy wieżyczek ozdobione są geometryczną dekoracją oraz datami: 1311 (która odnosi się do budowy pierwszego Dworu, chociaż jest to również data założenia bractwa artusowego) oraz 1891 (ukończenie budowy obecnego Dworu). Z zachowanych projektów autorstwa Schmidta wynika, że rozważał on również umieszczenie dat 1889 i 1890, co miałoby oznaczać prawdopodobnie lata rozpoczęcia i planowanego zakończenia budowy.

\section{Polichromia w sieni Dworu Artusa}

Jak wynika ze źródeł, w Dworze Artusa w XX w. systematycznie przeprowadzane były prace remontowe, mające na celu utrzymanie obiektu w jak najlepszym stanie. W 1904 r. remontowano budynek główny (prace malarskie), a w 1906 r. oficynę tylną. 11 lipca 1907 r. podpisano umowę $\mathrm{z}$ Hansem Rumschem $\mathrm{z}$ Wrocławia na wykonanie prac malarskich i tapeciarskich w budynku głównym, a wśród nich polichromii pokrywającej sklepienie krzyżowe w przedniej części parteru. Rumsch od 1901 r. był prezesem Związku Rzemiosła Artystycznego (Kunstgewerbeverein), a w 1904 r. został wybrany na głównego dekoratora wrocławskiej Wystawy Rzemiosła Artystycznego, której głównym projektantem był Hans Poelzig. Pracownia Rumscha znajdowała się we Wrocławiu przy Hohenzollernstraße $42^{18}$.

${ }^{18}$ APT, AmT, sygn. C 7386, k. 1-2. 
Hans Rumsch oprócz prac w toruńskim Dworze wykonywał między innymi dekoracje malarskie w gmachu dawnej Szkoły Rzemiosł Budowlanych i Wyższej Szkoły Budowy Maszyn we Wrocławiu (obecny Wydział Architektury Politechniki Wrocławskiej) ${ }^{19}$. Umowa, jaką magistrat Torunia zawarł z dekoratorem, zakładała ukończenie prac w Dworze z dniem 23 września 1907 r. Pierwsze miały zostać wyremontowane trzy górne małe sale. Po ich ukończeniu artysta mógł przystąpić do remontu Wielkiej Sali, pod warunkiem, że zawsze jedna jej połowa będzie nadawała się do użytku. W terminie wyznaczonym przez Urząd Nadzoru Budowlanego miały zostać przeprowadzone prace na parterze, w restauracji i na klatce schodowej. W umowie podkreślono, iż należy dołożyć wszelkich starań, aby podczas remontu nie ucierpiała działalność gospodarcza budynku. Wykonawca został zobowiązany do przestrzegania terminu i etyki pracy. Za każdy dzień opóźnienia z winy wykonawcy przewidziano karę w wysokości trzydziestu marek. Suma miała być potrącona $\mathrm{z}$ należnego wynagrodzenia. Po zaakceptowaniu prac przez magistrat, Hans Rumsch miał otrzymać kwotę w wysokości jedenastu tysięcy dwustu siedemnastu marek i dwudziestu dziewięciu fenigów, bez jakiejkolwiek dopłaty za ewentualne, dodatkowe prace nieujęte w kosztorysie. Płatność miała zostać dokonana przez magistrat po wykonaniu prac z zachowaniem dziesięcioprocentowej kaucji. Wartość materiałów oszacowano na tysiąc pięćset marek, a koszt wykonywanej pracy na dziewięć tysięcy siedemset siedemnaście marek i czterdzieści dziewięć fenigów. W końcowej części umowy zaznaczono, iż za jakość i trwałość prac odpowiada wykonawca przez dwa lata od momentu ich przejęcia. Dekoratora zobowiązano również do pokrycia kosztów wszelkich szkód, również tych powstałych na skutek

\footnotetext{
${ }^{19}$ Gmach ten powstał w latach 1902-1904. Podobnie jak w przypadku Dworu, jego korytarze przykryte zostały sklepieniami. Rumsch wykonał dekoracje w stylu secesyjnym. Symbolika przedstawień była prosta w odbiorze, nie zawierała skomplikowanych treści metaforycznych, zob. A. Gryglewska, Gmach dawnej Szkoły Rzemiost Budowlanych - siedziba Wydziatu Architektury Politechniki Wroctawskiej. Idea projektu, [w:] Schola Architecturae: budynki szkót architektury, pod red. O. Czernera, A. Gryglewskiej, Wrocław 2005, s. 82.
} 
prac remontowych, innych prac oraz szkód poniesionych przez dzierżawcę ${ }^{20}$.

Dziełem wrocławskiego dekoratora w toruńskim Dworze są między innymi malowidła na czterech polach sklepiennych w przednim trakcie parteru. Jest to sklepienie krzyżowe, którego pola podzielone są gurtami na cztery wysklepki. Pole północne, znajdujące się najbliżej wejścia, pokrywają sceny figuralne, tworzące przemyślaną narrację. Kolejne pola, w głębszej części parteru, zdobią abstrakcyjne ornamentalne wici roślinne, jednakowe w każdej z czterech części pola. Malowidła wykonane zostały w technice polichromii na otynkowanym podłożu i szczelnie pokrywają pola sklepienne.

Obserwator spoglądający pobieżnie na dekorację sklepienną mógłby odnieść wrażenie, że każda z czterech części przedstawia odrębną scenę. W rzeczywistości jednak poszczególne kwatery tworzą swego rodzaju opowieść zaprezentowaną $w$ formie panoramy. Narracja ta rozpoczyna się w części północnej, znajdującej się najbliżej wejścia, na której przedstawiono pochód grupy ludzi wychodzących z Ratusza Staromiejskiego (il. 1). Ich stroje wskazują na przynależność do grupy mieszczańskiej. Zostali oni ukazani w sposób perspektywiczny - wraz ze zbliżaniem się do krawędzi pola postacie powiększają się. Dodatkowy efekt zapewnia sam trapezoidalny kształt pola, rozszerzający się ku dołowi. Grupa wychodzi z jednego miejsca i rozdziela się na dwa szeregi. Mieszczanie idą „gęsiego”, jednak dzięki zastosowaniu perspektywy widoczna jest każda osoba.

Spośród pozostałych postaci szczególnie wyróżnia się mężczyzna trzymający szeroki, ciemnozielony sznur. Jest on podtrzymywany również przez kroczącą przed mężczyzną kobietę, której nakrycie głowy różni się od nakryć pozostałych kobiet ${ }^{21}$. Jest to prawdopodobnie towarzyszka lub małżonka mężczyzny znajdującego się na czele pochodu,

\footnotetext{
${ }^{20}$ APT, AmT, sygn. C 7386, k. 1-2.

${ }^{21}$ Jest to bardziej ozdobny i większy od czepca kornet w kolorze czerwonym, wykonany $\mathrm{z}$ tkaniny i dodatkowo usztywniony. W jego przedniej części można dostrzec zdobienia. Dodatkowym elementem kornetu są jasne wstążki, po dwie z każdej strony, opadające na ramiona kobiety. Jest ona odziana w niebieski płaszcz $\mathrm{z}$ jasnym podbiciem, które ukazują szerokie rękawy, i ciemniejszą suknię spodnią, a także czerwone obuwie z klamrami.
} 


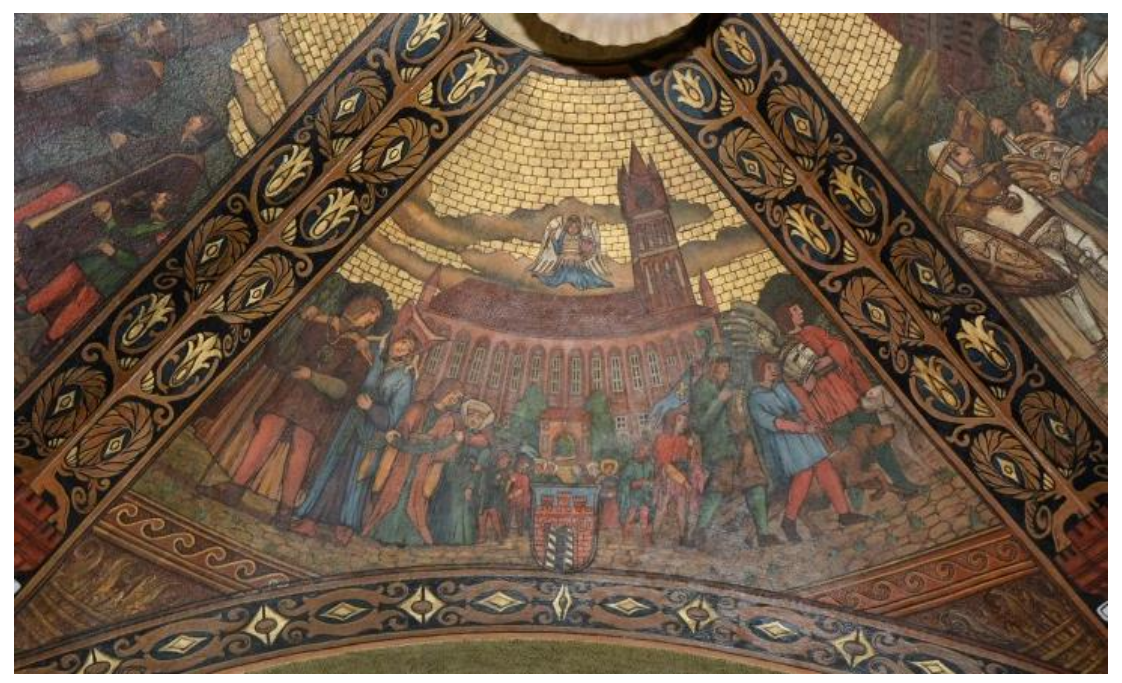

Il. 1. Północna część pola sklepiennego, przedstawiająca pochód mieszczan na tle Ratusza Staromiejskiego, fot. K. Dąbrowska

jej dłoń bowiem spoczywa na jego ramieniu, a on sam zwraca się ku damie. Mężczyzna ten wyraźnie różni się od pozostałych osób w tej kwaterze, co zostało zaznaczone za pomocą stroju. Prawdopodobnie jest on przedstawicielem bractwa kupieckiego, a jego towarzysze zaprezentowani zostali w kolejnej części pola sklepiennego. Umieszczono go przy krawędzi, jego postać stanowi bowiem płynne przejście do kolejnej warstwy społecznej, którą ukazano w kwaterze zachodniej. Mężczyzna odziany jest w strój bracki, na który składa się brunatna krótka tunika z rękawami sięgającymi łokci, długi płaszcz, spięty pod szyją, $\mathrm{z}$ jasnym podbiciem, i czerwone spodnie oraz brunatne obuwie $\mathrm{z}$ klamrami. Dodatkowym elementem podkreślającym jego przynależność do bractwa, a także wysoką pozycję społeczną, jest zawieszony u szyi kamień pieczętny $z$ herbem Torunia na łańcuchu oraz laska o długim trzonie i kulistym zakończeniu. Wniosek, jaki płynie z analizy strojów osób kroczących w tym szeregu, jest następujący: postacie zamykające pochód, znajdujące się najbliżej ratusza, są najmniejsze oraz najskromniej odziane. Zarówno suknie, jak i czepce kobiet są proste, pozbawione 
zdobień czy dodatkowych warstw. Strój kobiety zaprezentowanej jako druga w szeregu, towarzyszki członka bractwa, jest znacznie bogatszy, podobnie jak młodzieńca kroczącego za nią. Być może trzymany przez nich sznur ma podkreślać, iż postacie te odgradzają się od mniej zamożnych mieszkańców, należą do grupy bardziej elitarnej i nie chcą być utożsamiane $\mathrm{z}$ pozostałymi osobami w szeregu.

Analogicznie, ostatnia osoba w rzędzie po prawej stronie ukazana jest jako najmniejsza, przez co najsłabiej widoczna. Jest to mężczyzna w zielonej szacie, zwrócony w stronę Ratusza i wskazujący na niego ręką, jak gdyby w geście pochwalnym dla szacownej budowli. Przed nim ukazano dwie kobiety w żółtych czepcach. Widoczny jest jedynie ubiór drugiej kobiety, idącej z przodu - skromna, czerwono-niebieska suknia. Kolejną postacią w szeregu jest młodzieniec odziany w zieloną tunikę i czerwone spodnie. Następna osoba to również młody mężczyzna, na którego strój składa się czerwona krótka tunika, spod której wystają żółty rękaw oraz jasne spodnie. Niesie on niebieską chorągiew $\mathrm{z}$ żółtym krzyżem ${ }^{22}$. Twarze mieszczan ukazane zostały w sposób dość schematyczny. Nie widać na nich zróżnicowania emocji, można powiedzieć, że wszystkie wyglądają mniej więcej tak samo. Malarz zdecydowanie nie skupiał się na ukazaniu ich jako indywidualnych jednostek, lecz jako przedstawicieli konkretnego stanu. Postacie te były niezbędnym elementem do ukazania przekroju społeczności miejskiej, której kolejne grupy zostały zaprezentowane w sąsiednich polach. Malarz poświęcił wiele uwagi zróżnicowaniu strojów postaci, gdyż to właśnie ubiór od zawsze stanowił jeden z najprostszych komunikatów wizualnych na temat danej osoby czy jej przynależności do konkretnej warstwy społecznej ${ }^{23}$.

\footnotetext{
${ }^{22}$ Młodzieniec należy zapewne do służących rycerzom krzyżackim, zaprezentowanych we wschodniej części pola sklepiennego. Kolejne trzy postacie to pomocnicy i giermkowie. Pierwszy z nich odpowiedzialny jest prawdopodobnie za dwa psy myśliwskie, które prowadzone są na smyczach. Wskazuje na to jego myśliwski strój o barwie zielonej i brunatnej. Maszerują przed nim dwaj giermkowie. Jeden, niskiego wzrostu (być może jest to jeszcze chłopiec), trzyma psa na smyczy i odziany jest w niebieski krótki płaszcz, drugi niesie element rycerskiego uzbrojenia - hełm z bogatym pióropuszem, a jego ubiór to czerwony płaszcz do kolan.

${ }^{23}$ Popularne powiedzenie ,nie szata zdobi człowieka” jest oczywiście prawdziwe, jednak nie można zaprzeczyć, że często pierwszą informacją, jaką otrzymujemy pod-
} 
Monumentalna bryła Ratusza Staromiejskiego tworzy drugi plan przedstawienia. Nad budynkiem unosi się anioł z herbem Torunia, patronujący nad budynkiem, miastem i jego mieszkańcami. Fakt, iż pochód wychodzi właśnie z Ratusza nie jest przypadkowy, budynek ten bowiem od zawsze skupiał w sobie najważniejsze funkcje społeczne i był siedzibą władz miejskich. Dzieje toruńskiego Ratusza można podzielić na kilka okresów. W kontekście analizy malowidła o tematyce średniowiecznej interesujące są: pierwszy okres średniowieczny (od połowy XIII w. do około 1390 r.) oraz drugi okres średniowieczny (od 1390 do połowy XV w. $)^{24}$. Na polichromii zaprezentowany został Ratusz z drugiego okresu, o czym świadczą sama architektura oraz fakt, iż na jednej ze ścian przedsionka umieszczono herb Konrada von Wallenrode, który 14 maja 1393 r. wydał przywilej potwierdzający budowę nowego Ratusza (rozpoczęto ją już w roku 1391). Skrzydła nowego Ratusza zostały poszerzone, podwyższono wieżę, która jako jedyny element zachowała się ze starej zabudowy ${ }^{25}$. Materiał budynku to ciemnoczerwona cegła. Monumentalną bryłę urozmaicają narożne wieżyczki, umieszczone na hełmie wieży oraz w czterech narożnikach budynku. Nadają mu one pewnej lekkości. Na malowidle ukazano także przelot bramny Ratusza, zwieńczony herbem. Herb miasta umieszczono również w dole pola, w jego centralnej części. Na tej samej osi nad budynkiem „zawisnął” wspomniany wcześniej anioł, jeden z popularniejszych symboli miasta, znajdujący się obecnie w herbie. Co ciekawe, jego poza - klęczący, w błękitnej szacie - odpowiada stylistycznie okresowi, w którym malowidło powstawało. Dodatkowym elementem wzbogacającym kompozycję jest roślinność widoczna za budynkiem przez przelot bramny, rodzaj bujnego bluszczu wspinającego się po elewacji oraz drzewa i krzewy umieszczone na rynku, stanowiące rodzaj ramy dla przedstawienia. Ciekawym zabiegiem urozmaicającym dzieło jest

czas kontaktu z daną osobą, jest jej strój. W tym przypadku artysta wykorzystał tego typu prosty komunikat do poinformowania odbiorcy o pozycji społecznej osób wychodzących z Ratusza jako ostatnie.

${ }^{24}$ M. Woźniak, Ratusz Staromiejski w Toruniu. Dzieje - architektura - adaptacja, [w:] Ratusz w miastach pótnocnej Europy. Materiaty z sesji Ratusz w miastach nadbaltyckich, Gdańsk 25-27 XI 1993, pod red. S. Latoura, Gdańsk 1997, s. 157, 158.

${ }^{25}$ Ibid., s. 161. 
namalowany złotą barwą wątek ceglany zamiast nieba, stanowiący tło dla całej sceny. Miejscami przykrywają go, wprowadzające malowniczy efekt, złote chmury. Światło padające na niektóre fragmenty daje wrażenie połyskliwości, przez co malowidło może momentami imitować mozaikę ${ }^{26}$. Jak wspomniano wcześniej, pochód mieszczan płynnie przechodzi w pozostałe części pola sklepiennego, na których zaprezentowano kolejne, wyższe grupy społeczne. Grupa umieszczona w zachodniej części pola sklepiennego (il. 2) została „zapowiedziana” już w poprzedniej części przez giermków i psy, jest to mianowicie grupa rycerzy krzyżackich. W części tej umieszczono sześć osób. Są to, od lewej strony: rycerz w pełnym uzbrojeniu, białym krzyżackim płaszczu, z tarczą w prawej dłoni i chorągwią w lewej, następnie giermek (jego niski wzrost może świadczyć o młodym wieku, być może autor chciał podkreślić w ten sposób jego niską pozycję społeczną) w granatowym płaszczu do kolan i czerwonych rajtuzach, niosący hełm z pióropuszem. Kolejna osoba to rycerz rozmawiający $z$ idącym przed nim przedstawicielem bractwa. Ubiór rycerza to zbroja wzbogacona o granatową tunikę i czerwone wstążki przy hełmie. Niesie on miecz w pozycji poziomej, jak gdyby prezentując go obserwatorowi. Brat odziany jest $\mathrm{w}$ niemalże identyczną szatę $\mathrm{i}$ posiada te same atrybuty władzy (wisior, laska) jak poprzednik z pola północnego. Mężczyzna zdaje się gestem dłoni zapraszać rozmówcę do kontynuowania pochodu, jest zachęcający i uprzejmy. Następnymi osobami w szeregu i zarazem zamykającymi tę część pola są dwaj rycerze ubrani podobnie jak poprzednicy, ich szaty spodnie mają jednak kolor czerwony i urozmaicone są zdobnymi pasami. Miecz oraz tarcza pierwszego od lewej rycerza są większe niż u poprzedników, do hełmów również przytwierdzone są czerwone wstążki. Po raz kolejny można zauważyć podobieństwo do poprzedniego przedstawienia. Wraz ze zbliżaniem się do części południowej, w której znajdzie się scena „kulminacyjna”, rośnie ozdob-

\footnotetext{
${ }^{26}$ Być może pierwotnie planowano wykonać dzieło w tej technice, która mogła okazać się jednak zbyt kosztowna, dlatego poprzestano na polichromii. Warto zauważyć, iż technika mozaiki, typowa dla sztuki bizantyńskiej, wpisywałaby się w ideologię propagandową kreowaną przez cesarza Wilhelma II, który pragnął być kojarzony i utożsamiany z Konstantynem Wielkim, a z Prus stworzyć nową, ewangelicką Ziemię Świętą.
} 


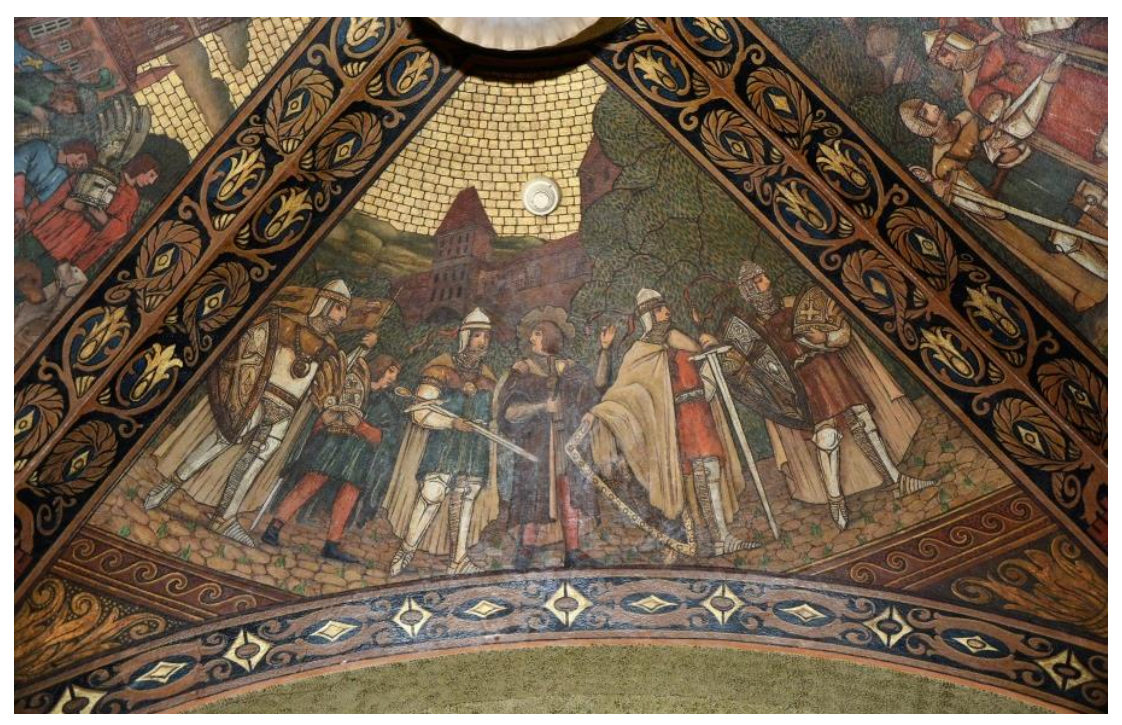

Il. 2. Zachodnia część pola sklepiennego grupa rycerzy na tle Bramy Chełmińskiej, fot. K. Dąbrowska

ność strojów przedstawionych osób. Przesłanka ta zdaje się zapowiadać, iż w części południowej zaprezentowane zostaną najwyższe rangą osoby.

Tłem dla grupy rycerskiej, jednego brata i giermka, jest element obwarowania średniowiecznego miasta. Jest to prawdopodobnie wyróżniająca się wysokością masywna Brama Chełmińska, która nie dotrwała do dzisiejszych czasów ${ }^{27}$. Jej warowno-militarny charakter dobrze koresponduje z rycerstwem zaprezentowanym na pierwszym planie. Na tej części pola sklepiennego malarz-dekorator zdecydował się na umieszczenie jeszcze większej ilości elementów roślinnych. Rosnące kaskadowo krzewy zostały namalowane w sposób schematyczny. Celem autora bez wątpienia nie było realistyczne przedstawienie za-

\footnotetext{
${ }^{27}$ Była to brama wieżowa, prawdopodobnie najwyższa brama miasta, wzniesiona na przełomie XIII i XIV w. Fakt, iż budowla ta stanowi tło dla przedstawienia, prawdopodobnie nie miał większego znaczenia symbolicznego. Jej usytuowanie odpowiada topografii miasta, tak więc pochód po prostu mijał ją na swej drodze do celu.
} 
zielenionych obszarów Starego Miasta. Roślinność została umieszczona tutaj prawdopodobnie w dwóch celach. Pierwszy z nich jest typowo dekoracyjny, urozmaicający przestrzeń. Drugi to być może chęć zakrycia pozostałych budowli Starego Miasta, sąsiadujących z Bramą, o których wyglądzie autor nie miał dostatecznej wiedzy i nie chciał przekłamywać rzeczywistości. Istnieje jeszcze jedna możliwość, mianowicie postacie ,zginęłyby” na tle architektury i jej skomplikowanych elementów. Gładkie tło, jakim jest roślinność, wprowadza ład i stanowi doskonały podkład dla ukazania rozmaitych strojów i detali przedstawianych osób. Za Bramą Chełmińską ukazano dość fantastyczny krajobraz - zielone doliny i pagórki. Tłem całego przedstawienia jest, podobnie jak w poprzedniej scenie, złoty wątek ceglany, gładki, nieprzykryty chmurami.

Jak wspomniano wcześniej, pochód mieszczan rozdziela się w dwie strony. W części wschodniej pola sklepiennego (il. 3) umieszczono więc postacie, które stanowią kontynuację lewego szeregu mieszczan. W części tej dekorator ukazał prawdopodobnie członków bractwa kupieckiego. Scena przedstawia siedmiu mężczyzn, w tym małego chłopca. Mężczyzna ostatni w szeregu trzyma chłopca za rękę, być może to jego syn. Chłopiec ubrany jest $\mathrm{w}$ jasnozieloną tunikę i czerwone spodnie, w ręku trzyma chorągiewkę. Wszyscy mężczyźni odziani są w jednolity strój bracki - brunatny, spięty pod szyją długi płaszcz z jasnym podbiciem, czerwone spodnie i ciemny kapelusz. Atrybutami podkreślającymi ich wysoką pozycję społeczną oraz uprawnienia polityczne są laska oraz spoczywająca na piersi pieczęć. Mężczyźni są tak samo przystrzyżeni. Braciom przewodzi rycerz $\mathrm{w}$ pełnym uzbrojeniu, który wspiera się na długim mieczu. Wśród osób zaprezentowanych w tej scenie wyróżniają się dwaj mężczyźni, trzeci i czwarty od prawej strony. Jeden $\mathrm{z}$ nich trzyma $\mathrm{w}$ ręku dokument $\mathrm{w}$ formie zwoju. Mężczyzna kroczący za nim również trzyma dokument, jednak rozwinięty. Postać ta ma oczy zasłonięte ciemną przepaską ${ }^{28}$. W tle pochodu widnieje kościół pod wezwaniem Najświętszej Marii Panny, widoczny od

\footnotetext{
${ }^{28}$ Być może w dokumentach tych zawarto statuty bractwa, które zostaną odczytane później, w miejscu, do którego kieruje się pochód, dlatego mężczyzna trzymający rozwinięty dokument nie może odczytać jego treści. W tej sytuacji podkreślone zostały
} 


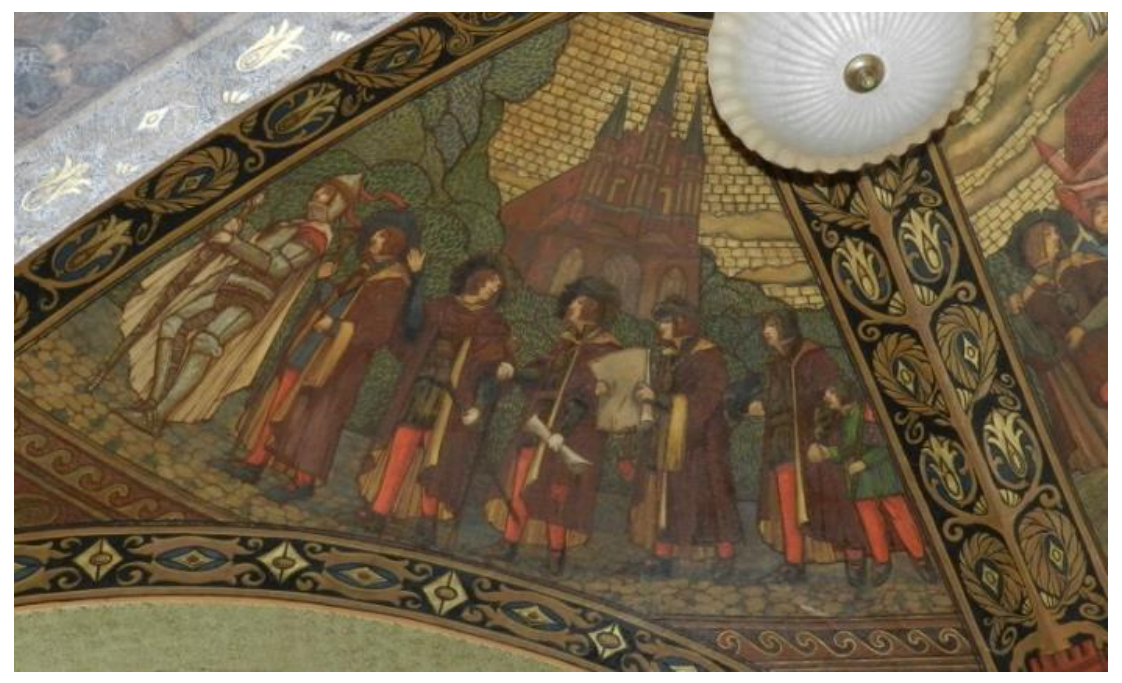

Il. 3. Wschodnia część pola sklepiennego, ukazująca prawdopodobnie członków bractwa kupieckiego, fot. K. Dąbrowska

strony Ratusza Staromiejskiego, co zgadza się z topografią miasta. Podobnie jak w poprzedniej scenie, budynek został otoczony gęstymi zaroślami, pnącymi się aż do górnego poziomu pola. Tłem dla budynku ponownie są malowany wątek ceglany w kolorze złotym i niewielkie obłoki.

W ostatniej części pola sklepiennego (strona południowa) można znaleźć odpowiedź na pytanie, dokąd zmierza pochód, w którym uczestniczą przedstawiciele wszystkich grup społecznych ukazanych w poprzednich scenach (il. 4). Celem wędrówki z Ratusza Staromiejskiego jest Dwór Artusa. W scenie tej centralną część zajmuje wnętrze Wielkiej Sali, które widać przez otwarte na oścież drzwi - jest to sklepiona sala, wsparta na kolumnie. Kolorystyka wskazuje na wyłożenie ścian oraz posadzki cegłą lub czerwonym marmurem. W pomieszczeniu znajdują się też ostrołuczne otwory okienne i długi stół, przykryty

praworządność i uczciwość członków bractwa, całego zgromadzenia i poszanowanie dla zasad, jakie obowiązują w mieście. Postać wywołuje skojarzenie z personifikacją sprawiedliwości, która zgodnie z tradycją przedstawiana jest z opaską na oczach. 


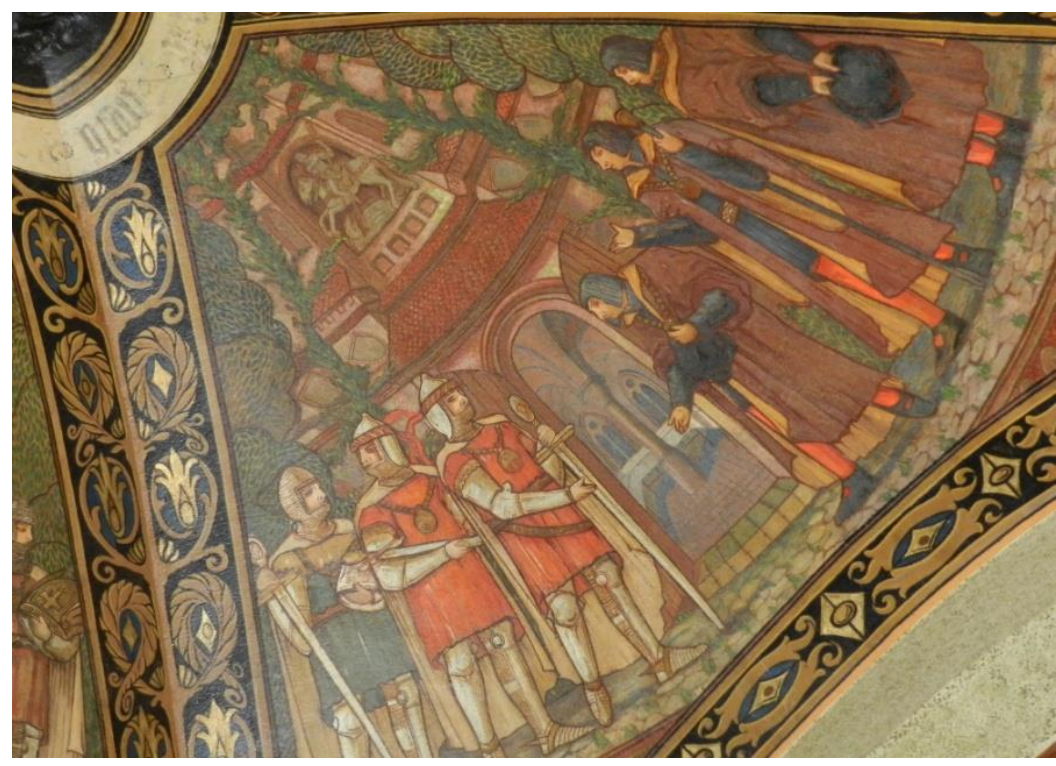

Il. 4. Południowa część pola sklepiennego,

centralnie przedstawiona została Wielka Sala Dworu Artusa cel pochodu najważniejszych mieszkańców i gości Torunia, fot. K. Dąbrowska

białym obrusem. Po obu stronach wejścia umieszczono symetrycznie po trzy postacie. Po lewej stronie ukazano prawdopodobnie wielkich mistrzów zakonu krzyżackiego. Być może są to Konrad Zöllner von Rotenstein i Konrad von Wallenrode, których herby znajdują się na ścianach poniżej sklepienia. Strój mistrzów to pełne uzbrojenie, czerwona suknia spodnia i biały płaszcz spięty pod szyją. Ich wysoką pozycję podkreślają okazała pieczęć na piersiach i długie miecze, a hełmy ozdobione są wstążkami. Trzecia postać to rycerz krzyżacki niosący element uzbrojenia, być może pomocnik. Rycerze ci jako pierwsi wchodzą do Dworu, są to więc najważniejsze osobistości z całego pochodu. Są oni gośćmi w mieście, traktuje się ich $\mathrm{z}$ wielką uprzejmością i kurtuazją.

Trzy postacie po prawej stronie drzwi to członkowie bractwa, ubrani tak samo jak poprzednicy; być może są oni wysokimi ławnika- 
mi, którym przypadła zaszczytna rola przewodniczenia swym braciom i pozostałym mieszkańcom Torunia. Są oni bardzo uprzejmi w stosunku do gości, których zapraszają do Dworu Artusa. Świadczą o tym kapelusze trzymane w dłoniach oraz gesty, które wykonują - pierwszy z braci, mający bezpośredni kontakt z rycerzem, pochyla się nisko i ruchem dłoni zaprasza gościa do środka.

Scena ta różni się od pozostałych, całe tło zajmuje bowiem fragment elewacji frontalnej średniowiecznego Dworu. Dodatkowym elementem identyfikującym budynek jako Dwór Artusa jest dekoracja zewnętrzna - rząd herbów umieszczonych pod skosem, zdobiący średniowieczną elewację Dworu, oraz liczne wnęki arkadowe. Centralną i największą wnękę zajmuje figura świętego Jerzego na koniu, zabijającego smoka $^{29}$. Podobnie jak w poprzednich częściach, w scenie nie brakuje zieleni. Fasadę porasta pnący bluszcz stanowiący swoistą ramę dla rzeźby ze świętym Jerzym, a po bokach znajdują się wysokie krzewy.

Malowidło pokrywające północne pole sklepienia przedstawia scenę przejścia mieszkańców Torunia wraz z krzyżackimi gośćmi z Ratusza do Dworu Artusa. W pochodzie zaprezentowane zostały rozmaite grupy społeczne, których identyfikacja możliwa była głównie dzięki ich strojom, atrybutom, niekiedy gestom i rozmiarom postaci. Najwyżsi rangą obywatele przewodzą pochodowi, gdyż jako pierwsi wyszli z Ratusza i zmierzają w stronę Dworu. Ci ubożsi i mniej ważni zamykają pochód. Biorąc pod uwagę wygląd sali w Dworze Artusa, stoły przykryte białymi obrusami, można dojść do wniosku, iż uczestnicy pochodu udają się na biesiadę, po oficjalnych uroczystościach.

Warto zauważyć, że w 1386 r. Konrad Zöllner von Rotenstein wydał przywileje dla nowo utworzonego bractwa Dworu, które powstało w wyniku połączenia bractwa kupieckiego i bractwa św. Jerzego. Rok wcześniej bractwo św. Jerzego zamierzało rozbudować skromny budynek klubowy, lecz nie dysponowało dostatecznymi środkami na ten cel. Z pomocą przyszło właśnie bractwo kupców zbożowych, które miało sfinansować sklepienie w Wielkiej Sali Dworu. Przebudowę

\footnotetext{
${ }^{29} \mathrm{Nie}$ jest to raczej zgodne z rzeczywistym wyglądem dawnego Dworu. Zabieg ten miał na celu podkreślenie związku bractwa ze świętym patronem i opieki, jaką roztacza on nad wszystkimi zgromadzonymi.
} 
zakończono w 1386 r., gdyż wówczas Dwór odwiedził wielki mistrz Konrad Zöllner von Rotenstein. Być może tematyka malowidła związana z jest tym wydarzeniem - dlatego ukazane zostało wnętrze sklepionej, wspartej na kolumnie Wielkiej Sali Dworu. Najwyższy przedstawiciel bractwa kupców zbożowych $\mathrm{z}$ dumą prezentuje wykonanie zadania.

Zwornik sklepienia zdobi dekoracyjny element ornamentalny w ciemnym kolorze, otoczony okrągłą taśmą, niegdyś pokrytą napisem, dziś niemożliwym do odczytania. Podobnie zdobiony jest zwornik pola sklepiennego w części południowej, z którego można odczytać słowa ladet oraz der haus. Napis ten dodatkowo potwierdza tezę, iż na malowidle goście są zapraszani (einladen - zapraszać) do Dworu Artusa, domu bractwa.

Ostatnie pole sklepienne, znajdujące się w najgłębszej części parteru, wyróżnia się dodatkową dekoracją. Na tle zielonej wici roślinnej dekorator umieścił średniowieczne postacie w pięknych, bogato zdobionych strojach. W części północnej znajduje się rycerz w pełnym uzbrojeniu, z długą kopią w dłoni. Rycerz ten ukazany został na koniu, którego również zdobi paradne i bogate uzbrojenie. Nawet ogon zwierzęcia, nierealistycznie poskręcany, komponuje się z fantazyjną wicią roślinną w tle. Podobną postać rycerza na koniu, zaprezentowaną w tej samej konwencji i różniącą się jedynie szczegółami, umieszczono $\mathrm{w}$ części południowej. W każdej z pozostałych dwóch części ukazano średniowieczną parę - damę dworu i jej towarzysza. Kobiety odziane są $\mathrm{w}$ bogato zdobione suknie, jedna z nich dodatkowo nosi kornet. Mężczyźni zostali zaprezentowani w przepasanych tunikach, płaszczach ze złotym podbiciem i ciżemkach z wysmukłym noskiem. Obaj zwracają się w stronę dam, w których towarzystwie dumnie kroczą. Postacie te ukazane zostały na polu sklepiennym bezpośrednio sąsiadującym z klatką schodową - być może malarzowi zależało na szczególnej dekoracyjności tego centralnego miejsca, w którym gromadziła się większa liczba osób odwiedzających Dwór. W ten sposób chciał również nawiązać do tradycji i dawnej funkcji budynku, w którym odbywały się liczne uroczystości, bale i spotkania towarzyskie. 
W tym miejscu należy zadać pytanie, dlaczego malowidła o dużym znaczeniu propagandowym znalazły się właśnie w sieni tak dużego obiektu, jakim jest Dwór Artusa, w którym nie brak bardziej reprezentacyjnych sal i przestrzeni? Dekoracja malarska prawdopodobnie nawiązuje do ważnego momentu w historii Dworu, jakim było połączenie się bractwa św. Jerzego z bractwem kupieckim. Nie byłoby to możliwe bez odpowiednich przywilejów wielkich mistrzów krzyżackich Siegfrieda von Feuchtwangen, który w 1310 r. wydał pozwolenie na powstanie patrycjuszowskiego bractwa św. Jerzego, oraz Konrada Zöllnera von Rotenstein, którego przywilej potwierdzał połączenie się dwóch bractw. Trzecim mistrzem, o którym „wspomniano”, jest Konrad von Wallenrode, związany z powstaniem Ratusza Staromiejskiego. Malowidło miało podkreślać fakt, iż najważniejsze wydarzenia w mieście, począwszy od jego założenia, miały miejsce dzięki związkom z zakonem krzyżackim i działalnością wielkich mistrzów. Dwór Artusa był instytucją, która jednoczyła przedstawicieli wszystkich stanów nawet tych najniższych. Mogli oni uczestniczyć w obchodach świąt lub być świadkami turniejów rycerskich. Być może malowidła umieszczono tuż przy wejściu do budynku, aby podkreślić ten specyficzny charakter budowli. Przekaz płynący z polichromii miał oddziaływać na każdego, kto odwiedza Dwór - być może tylko restaurację albo sklepy, niekoniecznie uczestnika oficjalnych uroczystości odbywających się w reprezentacyjnych salach na piętrze. W XX w. każdy z mieszkańców Torunia, niekoniecznie wysoko postawiony, miał mieć dostęp do malowidła, które ukazuje społeczny przekrój miasta w średniowieczu ${ }^{30}$.

\footnotetext{
${ }^{30}$ Styl, w jakim tworzył Hans Rumsch, nawiązuje do secesji. Świadczą o tym zamiłowanie do wici roślinnych, które tworzą dekoracyjne ornamenty, a także wyraźny kontur, zastosowany w przypadku scen figuralnych. Dodatkową dekoracyjność wprowadzają złota barwa i połyskliwość malowanego wątku ceglanego, który stanowi tło przedstawień. Zarówno treść, jak i forma malowideł nie są skomplikowane, co stanowi dodatkowe potwierdzenie tezy, iż dekoracja miała być dostępna i czytelna dla każdego, kto odwiedzał Dwór.
} 


\section{Sztuka jako narzędzie propagandy państwa pruskiego na terenie Prus Zachodnich}

Okres panowania pruskiego w Toruniu przyniósł więcej realizacji o wysokim poziomie artystycznym, nie wszystkie jednak miały tyle szczęścia, co malowidła w Dworze Artusa, i nie zachowały się do dzisiejszych czasów - zostały usunięte po pierwszej wojnie światowej, kiedy to tereny dawnego zaboru pruskiego przejęła polska administracja. Głównym elementem obcej, niemieckiej kultury w miastach Pomorza były budynki wykonane $\mathrm{z}$ czerwonej cegły w stylu neogotyckim, demonstrujące narodowe tradycje i będące legitymizacją cesarstwa $^{31}$. Dzieła przypominające o trudnych czasach klęsk i zaborów, określane nieraz jako „prusactwo”, były, zgodnie z aprobatą polskich władz, konserwatorów i urbanistów, niszczone lub przebudowywane. Są one dziś określane jako „niechciane dziedzictwo" ${ }^{32}$.

Popularnym sposobem przemycania pruskich treści propagandowych w formie artystycznej były uzupełniające architekturę pomniki gloryfikujące cesarza Wilhelma I, kanclerza Bismarcka oraz mistrzów zakonu krzyżackiego. Jako przykład można podać toruński most kolejowy, a dokładnie - zdobiące go, nieistniejące dziś figury i płaskorzeźby. W niszach mostu usytuowano posągi króla pruskiego Fryderyka II i cesarza Wilhelma I oraz mistrzów krzyżackich Hermana Balka i Hermana von Salza. Dodatkowym elementem wskazującym na rolę Prus w kształtowaniu i cywilizowaniu podbijanych terenów były zdobiące most płaskorzeźby ${ }^{33}$. Miały one w sposób jasny i czytelny informować zarówno mieszkańców, jak i podróżnych o niemieckich zwycięstwach, którym przewodziły wybitne jednostki. Niezmiennie jako ideał, do którego odwoływano się niemal w każdej z płaskorzeźb, traktowano zakon krzyżacki. Jego przedstawiciele schrystianizowali

\footnotetext{
${ }^{31}$ M. Bandrowicz, M. Przegiętka, Niechciane dziedzictwo? Usunięcie niemieckich posagów i plaskorzeźb z mostu na Wiśle w Toruniu w latach dwudziestych XX wieku, Rocznik Toruński, t. 37, 2010, s. 164.

${ }^{32}$ Ibid., s. 163 .

${ }^{33}$ Ilustrowały one postępy niemieckiej cywilizacji i kultury, nawracanie pogan w Prusach, moment założenia miasta przez wielkiego mistrza zakonu krzyżackiego Hermana Balka oraz wkroczenie wojsk pruskich do miasta w $1793 \mathrm{r}$.
} 
pogańskie ziemie, dzięki czemu reprezentują one do dziś godny poziom cywilizacyjny. $Z$ dumą podkreślano również fakt, że to właśnie wielki mistrz był założycielem miasta. Dekoracje toruńskiego mostu były wartościowym źródłem historycznym, mówiącym wiele o ówczesnych stosunkach politycznych, aspiracjach zaborcy i sposobie, $\mathrm{w}$ jaki wyrażano treści, które miały trafić do szerokiego grona odbiorców. Miały również wysoki poziom artystyczny.

Kolejnym przykładem pruskiego dziedzictwa są wolno stojące pomniki. Niegdyś rzadko spotykane $\mathrm{w}$ mieście, stały się popularne $\mathrm{w}$ XIX w., były bowiem doskonałym sposobem na trwałe wyrażenie treści politycznych i upamiętnienie niemieckich bohaterów. Pomniki wznoszono w najważniejszych punktach miasta, miejscach, gdzie byłyby szczególnie wyeksponowane i spełniałyby swoje funkcje ideologiczne $^{34}$. Jednym z nich był tzw. „Kriegerdenkmal” - Pomnik Poległych, największy w Toruniu. Upamiętniał on pruskich żołnierzy pochodzących z powiatu toruńskiego poległych w walkach z Danią w 1864 r., z Austrią w 1866 i Francją w 1870-1871 ${ }^{35}$. Wymowa pomnika była jasna - była to komemoracja pruskich żołnierzy, którzy pochodzili $\mathrm{z}$ okręgu toruńskiego i zginęli w czasie wojen. Władze niemieckie podkreśliły $\mathrm{w}$ ten sposób zaangażowanie niemieckich obywateli w walkę o potęgę swego państwa i ku chwale cesarza.

Niemieckie władze i stowarzyszenia przykładały szczególną wagę do wystawiania propagandowych monumentów, które czciły najważniejsze osoby państwa pruskiego - Wilhelma I oraz kanclerza Bismarcka. Tego typu pomników nie mogło zabraknąć również w Toruniu. Pierwszy został usytuowany w najbardziej prestiżowej lokalizacji, w zachodniej części Rynku Staromiejskiego, przed elewacją Ratusza, gdzie stanął w 1904 r. Dzieło to stanowiło centrum najważniejszych uroczystości państwowych. Mniej więcej w tym samym czasie, kiedy starano się o wzniesienie w Toruniu pomnika cesarza, trwały zabiegi dotyczące upamiętnienia kanclerza Otto von Bismarcka. Rok po śmierci

\footnotetext{
${ }^{34}$ Warto podkreślić, iż w okresie Cesarstwa Niemieckiego przyznawano specjalne fundusze na upiększanie miast, zwłaszcza jeżeli dotyczyło to wznoszenia dzieł o wymowie propagandowej.

${ }^{35}$ Ibid., s. 109.
} 
kanclerza, w styczniu 1899 r. rozpoczęto dyskusje na temat lokalizacji nowego pomnika, a w zasadzie kolumny wykonanej z granitu. Zdecydowano się na teren Parku Cegielnia, na skwerze niedaleko skrzyżowania dzisiejszych ulic Reja i Bydgoskiej. Znajdował się on w pewnej odległości od centrum, ale był jednocześnie często i tłumnie odwiedzany, w takim więc miejscu pomnik nie popadłby w zapomnienie, lecz żywo oddziaływałby na spacerujących.

Warto dodać, że elementem niemieckiej propagandy były nie tylko pomniki upamiętniające osoby związane z polityką, lecz również znanych przedstawicieli kultury, będących dumą narodu niemieckiego. Jako przykład można podać posąg Jana Gutenberga na fasadzie kamienicy przy ul. św. Jadwigi 4, ławeczkę Schillera w Parku Miejskim oraz pomnik Mikołaja Kopernika na Rynku Staromiejskim.

Podczas pruskiego panowania $\mathrm{w}$ Toruniu dążono do manifestacji niemieckości albo - jak niegdyś mówiono - „prusactwa” nie tylko poprzez wznoszenie pomników i dekorowanie najchętniej uczęszczanych miejsc nawiązaniami do związków Torunia z Prusami czy niemieckimi bohaterami. Istotnym, aczkolwiek nieoczywistym sposobem na wyrażenie nacjonalistycznej ideologii było stosowanie konkretnych stylów w architekturze. Podczas pierwszych dziesięcioleci pruskiego panowania $\mathrm{w}$ Toruniu skupiono się na budownictwie obronnym i zaspokajaniu potrzeb miejskiej infrastruktury. Po wykonaniu tego zadania punkt ciężkości przeniósł się na inwestycje związane ze szkolnictwem, kulturą czy budownictwem mieszkaniowym. W pierwszej dekadzie XX w. Toruń zyskał tzw. Ring. Oznaczało to, iż na miejscu zlikwidowanych fortyfikacji z czasów średniowiecza zbudowano teatr, bank, budynki sądu, starostwa, policji, kościoła kalwińskiego, straży pożarnej i szkoły rzemieślniczej ${ }^{36}$. W ten sposób opasano starówkę pierścieniem reprezentacyjnej zabudowy, na wzór najbardziej okazałego Ringu wiedeńskiego. To właśnie Niemcy byli pierwszym narodem, w którym narodziła się potrzeba tworzenia we własnym stylu. Postawy nacjonalistyczne w tym kraju zaczęly się pojawiać na początku XIX w., po okresie wojen napoleońskich, chociaż pierwsze symptomy były już

\footnotetext{
${ }^{36}$ M. Pszczółkowski, Toruńska architektura XX wieku, Toruń 2011, s. 11.
} 
widoczne w XVIII w., czego przejawem były postulaty autorstwa Goethego, nakłaniające do tworzenia narodowej architektury.

Zarówno zabytki mówiące w sposób oczywisty o treściach propagandowych, jak i życiorysy oraz dzieła artystów czasów pruskich w Toruniu odeszły w zapomnienie. Elementy kojarzące się z trudnymi czasami nie miały większych szans na przetrwanie, dawni artyści czasów pruskich nie doczekali się osobnej wystawy. Mieszkańcy nieinteresujący się historią swego miasta i jego nieistniejącymi już zabytkami zapewne nie zdają sobie sprawy, że Toruń zdobily niegdyś niemieckie dzieła o dużej wartości artystycznej i historycznej. Na tym tle zachowane malowidła zdobiące przedsionek Dworu Artusa zdają się być swego rodzaju fenomenem. Być może dekoracja, która informowała między innymi o znaczącej roli wielkich mistrzów krzyżackich, nie była dla polskich obywateli elementem obcego dziedzictwa?

Należy zastanowić się, czy treści zawarte w omawianej polichromii mają charakter lokalny czy państwowy - niemiecki. Sceny figuralne przedstawiają ważny moment dla historii Torunia - połączenie się bractwa rycerskiego z bractwem kupieckim. Jak wykazano wcześniej, wydarzenie to łączyło przedstawicieli wszystkich warstw społecznych, było powodem do radości i świętowania, co prawdopodobnie miało miejsce w dawnym Dworze. Można więc przypuszczać, iż wśród wszystkich przykładów pruskiej polityki wizualnej najbardziej lokalny charakter miała dekoracja malarska w Dworze i dzięki temu nie zniszczono ani nie zamalowano jej po odzyskaniu Torunia. Na sklepieniu w sieni nie ukazano wydarzeń źle kojarzących się mieszkańcom, tak jak w przypadku dekoracji mostu kolejowego. Przeciwnie - skupiono się na wydarzeniach pozytywnych, takich, które przyczyniły się do rozwoju miasta. W reprezentacyjnych salach, znajdujących się na wyższych kondygnacjach, nie brak powierzchni, które mogły zostać pokryte propagandowymi treściami. Zamiast tego zdecydowano się na neutralne $\mathrm{w}$ wymowie dekoracje ornamentalne oraz sceny nawiązujące do mitologii, a więc tematy „bezpieczne”.

Elementy nawiązujące do ideologii cesarskiej zostały z kolei umieszczone, w nieoczywisty na pierwszy rzut oka sposób, na zewnątrz budynku. Niemieccy architekci przełomu XIX i XX w. styl neorenesan- 
sowy (w odmianie północnej) uznawali za narodowy, a więc najbardziej odpowiedni dla oficjalnych, reprezentacyjnych budowli. Niektórzy badacze zajmujący się architekturą Dworu Artusa dopatrują się w tym przejawów importu obcego gustu, który negatywnie wpłynął na zagospodarowanie Rynku Staromiejskiego. Budynek faktycznie wyróżnia się swym rozmiarem, jednak styl, w jakim został wzniesiony, nie kłóci się z zabytkową architekturą starówki, a ciemnoczerwona barwa elewacji dobrze komponuje się $\mathrm{z}$ gotyckimi zabudowaniami. Omawiana odmiana stylu neorenesansowego była popularna i ceniona głównie ze względu na swoje mieszczańskie konotacje, co z kolei koresponduje $\mathrm{z}$ historią budynku, który był przecież niegdyś miejscem najbardziej związanym z tą warstwą społeczną.

Nie można jednak zaprzeczyć, iż szata architektoniczna Dworu była elementem manifestacji treści państwowych, mających związek z polityką. Zarówno tworzenie budowli w stylu narodowym, jak i wznoszenie propagandowych pomników czy dekoracji miało jasny przekaz - Niemcy zostają w Toruniu na stałe. Jeśli chodzi o sam Dwór Artusa, płynie $\mathrm{z}$ tego ciekawy wniosek, iż budynek na zewnątrz pozostawał niemiecki, w środku zaś toruński. Architektura i dekoracja fasady, a więc to, co widoczne jako pierwsze, informowały o związkach z cesarstwem, był to rodzaj manifestacji. Z kolei wewnątrz odwołano się do historii Torunia - w zasadzie już po przekroczeniu progu można było dowiedzieć się o istotnych dla miasta i samego budynku wydarzeniach. Być może poprzez umiejscowienie dekoracji o treściach lokalnych tuż przy wejściu chciano podkreślić fakt, iż jest to przede wszystkim zabytek toruński. Malowidła o charakterze lokalnym umieszczono w ważnym, lecz nie najbardziej reprezentacyjnym miejscu, jakim były sale na wyższych kondygnacjach.

Dwór Artusa był jednym z ważniejszych przykładów sztuki w służbie pruskiej propagandy w Toruniu. Świadczą o tym zarówno szata architektoniczna budynku, jak i dekoracja malarska wewnątrz, które razem stanowią wypadkową nurtów lokalnych oraz związków z mecenatem państwowym ${ }^{37}$. Wyjątkowość dekoracji w sieni polega na tym,

${ }^{37}$ Odpowiedzi na pytanie, dlaczego XIX-wieczny Dwór Artusa został wybudowany w stylu neorenesansowym, należy szukać w pojęciu nacjonalizmu i stylów narodo- 
iż ukazuje wydarzenie, które można odczytywać w dwojaki sposób: jako ważny moment dla torunian, jak również korzystny z perspektywy niemieckiej. Takiego szczęścia nie miało wiele toruńskich pomników. Co więcej, w zapomnienie poszły nazwiska wielu artystów, którzy tworzyli w czasach pruskich, a ich dzieła wzbogacają kolekcje najważniejszych muzeów na całym świecie. Być może artyści ci doczekają się jeszcze solidnego opracowania lub dużej wystawy.

Toruński Dwór Artusa, jako budynek reprezentujący jeden z niemieckich stylów narodowych, mógł również paść ofiarą „odprusaczania" - co na szczęście się nie stało. Tego typu sytuacja zaistniała na przykład w Olsztynie. Na rynku, w miejscu oryginalnych, pruskich fasad kamienic z połowy XIX w. zdecydowano się umieścić fasady pseudobarokowe ${ }^{38}$.

W dzisiejszych czasach jesteśmy świadkami bardzo podobnej sytuacji - mowa o usuwaniu pomników żołnierzy radzieckich oraz zmienianiu nazw ulic, które kojarzą się z czasami komunizmu. Jak widać, krzywdzące czasy i towarzyszące im negatywne wydarzenia, związane z licznymi upodleniami i cierpieniem, od zawsze żywo oddziaływały na naród nawet po kilkudziesięciu latach. Być może dopiero po upływie stulecia można zdobyć się na osiągnięcie pewnego dystansu i ocenianie dzieł propagandowych $\mathrm{w}$ kryteriach artystycznych czy jako rodzaj historycznego dokumentu.

\section{Bibliografia}

Archiwalia

Wojewódzki Urząd Ochrony Zabytków w Toruniu:

Szczerbiński S., Dwór Artusa. Toruń, Rynek Staromiejski 6: dokumentacja historyczno-konserwatorska, Torun 1989, mps.

Źródła niepublikowane

Archiwum Państwowe w Toruniu:

wych, które chętnie stosowano po zjednoczeniu Niemiec. W przypadku Dworu Artusa wybór wręcz „musiał” paść na neorenesans ze względu na jego mieszczańskie konotacje.

${ }^{38}$ M. Zybura, Pomniki niemieckiej przeszłości. Dziedzictwo kultury niemieckiej na Ziemiach Zachodnich i Pótnocnych Polski, Warszawa 2009, s. 20. 
Akta miasta Torunia, sygn. C 7386

Akta miasta Torunia, sygn. G 3994.

Źródła publikowane

Gazeta Toruńska 1889, nr 145, 27 VI.

Literatura

Bandrowicz M., Przegiętka M., Niechciane dziedzictwo? Usunięcie niemieckich posagów i plaskorzeźb z mostu na Wiśle w Toruniu w latach dwudziestych XX wieku, Rocznik Toruński, t. 37, 2010.

Czacharowski A., Toruń średniowieczny (do roku 1454), [w:] Toruń dawny i dzisiejszy. Zarys dziejów, pod red. M. Biskupa, Warszawa 1983.

Gryglewska A., Gmach dawnej Szkoty Rzemiost Budowlanych - siedziba Wydziatu Architektury Politechniki Wroctawskiej. Idea projektu, [w:] Schola Architecturae: budynki szkót architektury, pod red. O. Czernera, A. Gryglewskiej, Wrocław 2005.

Heuer R., Die Drei Artushöfe und der Junkerhof in Thorn, Thorn 1917.

Kucharzewska J., Architektura i urbanistyka Torunia w latach 1871-1920, Warszawa 2004.

Pilecka E., Średniowieczne Dwory Artusa w Prusach Zachodnich. Świadectwo ksztaltowania się nowej świadomości mieszczańskiej, Torun 2005.

Pszczółkowski M., Toruńska architektura XX wieku, Toruń 2011.

Woźniak M., Ratusz Staromiejski w Toruniu. Dzieje - architektura - adaptacja, [w:] Ratusz w miastach pótnocnej Europy. Materiaty z sesji Ratusz w miastach nadbattyckich, Gdańsk 25-27 XI 1993, pod red. S. Latoura, Gdańsk 1997.

Zybura M., Pomniki niemieckiej przeszłości. Dziedzictwo kultury niemieckiej na Ziemiach Zachodnich i Pólnocnych Polski, Warszawa 2009. 